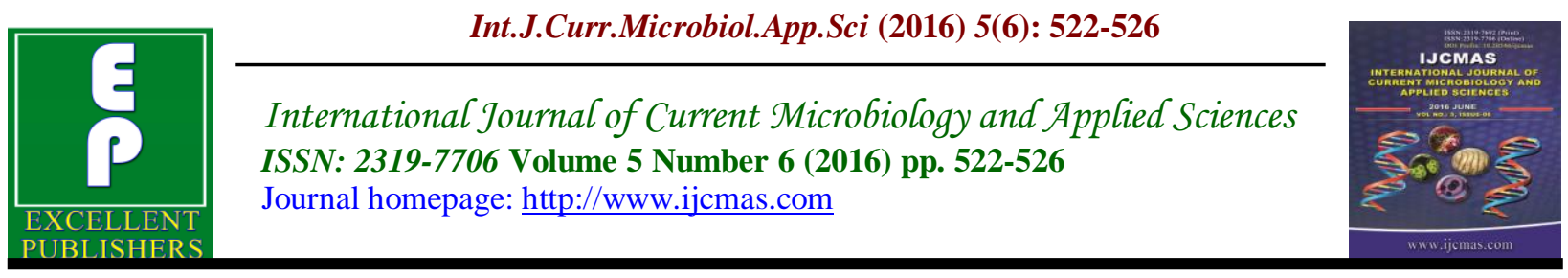

Original Research Article

http://dx.doi.org/10.20546/ijcmas.2016.506.058

\title{
Parasitism Efficacy of Two Isolates of the Fungus Beauveria bassianato Control Larvae and Pupae of Melon fly Dacus frontalis
}

\author{
Husam A. Ldeen, Abdaluh Mohammed, Sawsan Kareem Flaih, \\ Nabaa Abdulridha Mikheef and Majeed Hameed Nawar
}

Department of Plant Protection, College of Agriculture, University of Baghdad, Iraq

*Corresponding author

\begin{tabular}{|c|c|}
\hline & A B S T R A C T \\
\hline & \multirow{12}{*}{ 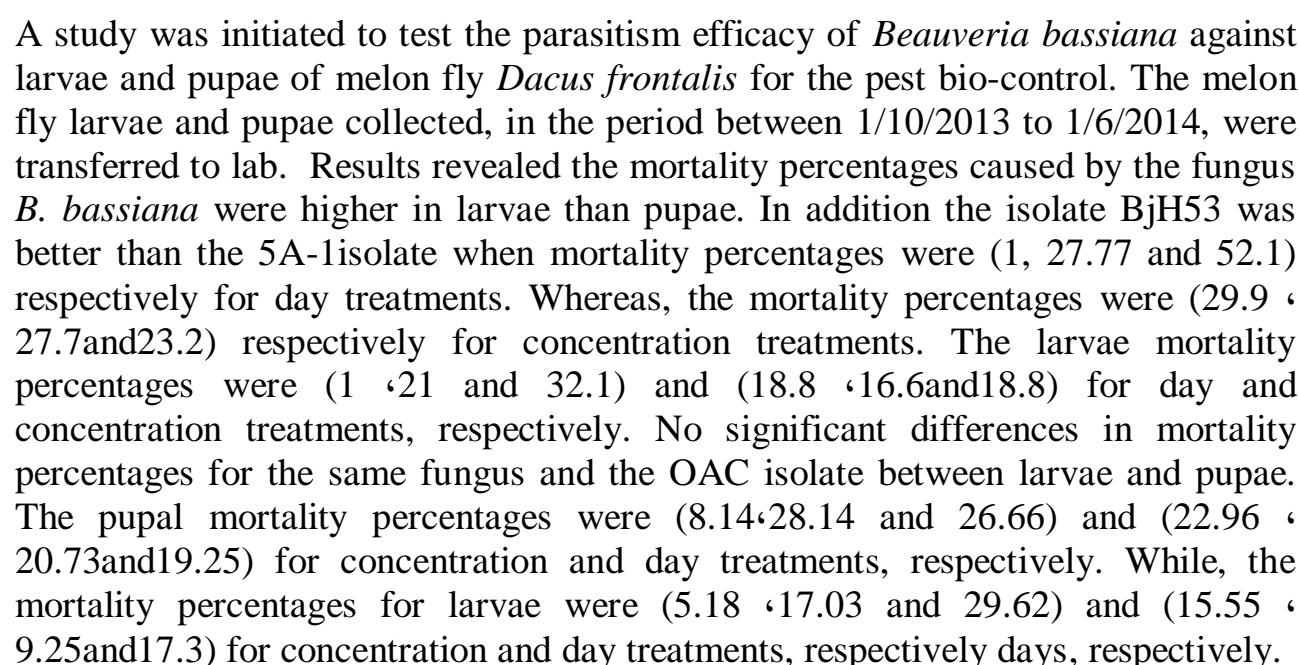 } \\
\hline & \\
\hline & \\
\hline & \\
\hline & \\
\hline & \\
\hline & \\
\hline Art & \\
\hline & \\
\hline & \\
\hline & \\
\hline & \\
\hline
\end{tabular}

\section{Introduction}

Cucumber (Cucumis sativus L.) is one of the most important cucurbitaceous crops in Iraq and worldwide, within the family Cucurbitaceae. The possible origins of cucumber are India an d Africa (Al.Sahaf et al., 2011). Cucumber is attacked by several pests including sweet potato white fly Bemisiata baci, thrips (Thripsta baci, T. palmi) (Al.Sahaf et al., 2011; Hamodi and mohammad, 2012; Mahdi, 2000), aphids Aphis spp.andred pumpkin beetle (Rhaphidopalpa foveicollis). It can be infested by arthropods including the two spotted spider mite Tetrany chusurtica in Spring and Autumn seasons. Melon fly Dacus frontalis is one of the most important pest that limits cucumber production in Iraq. The damage caused by this insect depends on host plant and environmental conditions. The damage caused by melon fly on its hosts, mainly cucurbitaceous hosts, may reduce fruit quality like holes made due to oviposition, resulting fruit wrinkling or distortion. More damage occurs due to 
larvae feeding on fruit flesh and seeds causing fruit decaying (Azab and Kira, 1954). Many approaches, including microbial control, were used to control melon fly. (Sinha and Sexena, 1999) concluded the application of Trichoderma viridae Pers., Rhizoctonia solani Kuhn and Gliocladium virens Origen filtrates reduced the oviposition development of Bactrocera cucurbitae adults. The effectiveness and efficacy of biological control agents infields are not clear, therefore, they are required further assessment before field and IPM applications. (Sookar et al.,2008) revealed that the pathogenicity of 5 local isolates of Beauveria bassiana pathogenicity applied through surface treatment of were highly efficient to control Bactrocera cucurbitae adults within five days when mortality percent ranged between (2-94\%).

\section{Materials and Methods}

Infected fruit collected from vegetable field at Plant Protection Department/College of agriculture-Abu Ghraib were sliced to $1 \mathrm{~cm}^{2}$ pieces then placed with larvae and pupae in $9 \mathrm{~cm}$ Petri-dishes containing filter papers. Beauveria bassiana $\mathrm{Bj} \mathrm{H} 53$ and $5 \mathrm{~A}-1$ isolates were suspended on potato dextrose agar (PDA) (Himedia Laboratories Limited) (prepared by adding $39 \mathrm{~g}$ per 1 liter distilled water then autoclaved for 40 mint. At $121 \mathrm{C}^{\circ}$ and 1.5 bar). The PDA was poured in $9 \mathrm{~cm}$ Petri-dishes then kept inverted at $4 \mathrm{C}^{\circ}$ up to use. The fungus isolates were grown on PDA by picking $3 \mathrm{~mm}$ pieces from fungal culture using cork borer then placing each piece in the middle of the PDA containing plates. Plates were incubated for 5 days at $\pm 22 \mathrm{C}^{\circ} \quad$ (Jassim, 2007). To test the pathogenicity of fungal isolates on the melon fly $D$. frontalis larvae an pupae at laboratory conditions, three concentrations $\left(1 \times 10^{4}, \quad 1 \times 10^{6}\right.$ and $1 \times 10^{8}$ spore $\left./ \mathrm{ml}\right)$ were tested against melon fly larvae and pupae. Insects were placed in glass plates containing filter papers, then sprayed with $300 \mathrm{ml}$ fungal suspension for each concentration using a hand sprayer. Insects were sprayed by distilled water for control treatment. Plates containing treated insects were incubated in a growth chamber at \pm $22 \mathrm{C}^{\mathrm{o}}, 70 \%$ relative humidity and $12 \mathrm{~h}$ light period. Mortality percent were calculated after 1, 3 and 4 days of treatments using direct examination by light microscopy.

\section{Results and Discussion}

Table 1 shows relative activity of Beauveria bassaina against Dacus frontalis larvae and pupae. Mortality percentages were higher in pupae $(29.9 \%)$ than larvae after $24 \mathrm{~h}$ exposure time for $1 \times 104 \mathrm{spore} / \mathrm{ml}$ treatment. Mortality percentages were 27.7 and 23.2 after 72 and $96 \mathrm{~h}$ exposure time for $1 \times 106$ and $1 \times 108$ spore $/ \mathrm{ml}$ treatments respectively. Significant differences were shown clearly for larvae mortality percentages by fungus based on concentrations and exposing time when the less significant difference was 6.06. Besides, larvae mortality percentages were proportionally correlated to concentrations and exposing time. Mortality percentages were $18.8 \%$ for both $1 \times 104$ and $1 \times 108$ and $16.6 \%$ for $1 \times 106$ spore $/ \mathrm{ml}$ concentrations. LSD value between time and concentration averages was 10.53 , whereas it was 6.08 for days. Mortality percentages increased per days after $24 \mathrm{~h}$ of treatment and became more obvious by 27 and $86 \mathrm{~h}$ after of treatment which increased gradually for all days (27.7 and 23.2). The above results suggest the efficacy of Beauveria bassaina to kill Dacus frontalis larvae despite the chitin layer covering their bodies. Chitin represents an essential barrier to protect the insect against pesticides and microbe invasion (Heinz et al., 2004). 
Table.1 Relative activity of Beauveria bassiana isolate 1 against Dacus frontalis larvae and pupae

\begin{tabular}{|c|c|c|c|c|}
\hline \multicolumn{2}{|c|}{$\begin{array}{l}\text { Mortality Rate for } \\
\text { pupae }\end{array}$} & \multicolumn{2}{|c|}{$\begin{array}{c}\text { Mortality Rate } \\
\text { for fungus } \\
\text { B.bacssiaua, } \\
\text { D.frontalis }\end{array}$} & \multirow[t]{2}{*}{ Concentration } \\
\hline concentration & rate & concention & Rate & \\
\hline 29.9 & 1 & 18.8 & 1.0 & ${ }^{4} 10 \times 1 / 24 H$. \\
\hline 27.7 & 27.7 & 16.6 & 21.0 & ${ }^{6} 10 \times 1 / 72 H$. \\
\hline 23.2 & 52.1 & 18.8 & 32.1 & ${ }^{8} 10 \times 1 / 96 \mathrm{H}$. \\
\hline \multicolumn{2}{|l|}{6.93} & \multicolumn{2}{|l|}{6.08} & LSD \\
\hline \multicolumn{2}{|l|}{12.01} & \multicolumn{2}{|l|}{10.53} & LSD for time \\
\hline
\end{tabular}

Table.2 Relative activity of Beauveria bassiana isolate 2 against Dacus frontalis larvae and pupae

\begin{tabular}{|c|c|c|c|r|}
\hline \multicolumn{2}{|c|}{ Pupae } & \multicolumn{2}{c|}{ Larvae } & $\begin{array}{r}\text { Time } \\
\text { Comcentaration }\end{array}$ \\
\cline { 1 - 4 } Concentration & rate & Concention & Rate & $\mathbf{1 0}^{4} \times 1 / 24$ hour \\
8.14 & $\begin{array}{c}22 . \\
96\end{array}$ & 5.18 & 15.55 & \\
\hline 28.14 & 20. & 17.03 & 19.25 & $\mathbf{1 0}^{6} \times 1 / 72$ hour \\
\hline 26.66 & 19. & 29.62 & 17.03 & $\mathbf{1 0}^{8} \times 1 / 96$ hour \\
\hline 14.9 & 25 & \multicolumn{2}{|c|}{15.3} & LSD \\
\hline 13.8 & \multicolumn{2}{|c|}{14.6} & LSD Avg \\
\hline
\end{tabular}

This fungus, when conidia germinate, form germ tubes and excrete chitinase and proteinase which cleave chitin and protein respectively. Beside excreting the mycotoxin Beauvericin, known to be toxic to several insects, affecting the ionic balance necessary for cell activities, the fungus, therefore, is able to invade the insect body (Mazel and Boucias, 1996). Similar results shown when this fungus isolate was applied to different pests infesting other plants when (Ferron and Vincant, 1978) found that apple maggot larvae in the last stage were most sensitive to be infected by this fungus compared to first stage larvae.
Results presented in table 2 revealed mortality rates caused by Beauveria bassaina 2ndisolatein 2nd stage larvae raised by concentration increase which were $(5.18,17.3$ and 26.62$) \%$ at $(1 \times 104,1 \times 106$ and $1 \times 108)$ spore $/ \mathrm{ml}$ concentrations, respectively. Whereas, mortality were $(15.55 ، 19.25,17.03) \%$ after 24,72 and $96 \mathrm{~h}$ treatments, respectively. Pupae mortality percentages were $(8.14$ ،28.14, 26.66)\% for the same concentrations, respectively. Whereas mortality percentages per days up to $(22.96 \cdot 20.73,19.25) \%$ after 24,72 and $96 \mathrm{~h}$ treatments, respectively as statistical analysis showed no significant differences. 
As (Charnley et al., 1997) indicated Beauveria bassaina mycelium, once penetrating the body wall, excretes the enzyme attacks fatty bodies, as well as the toxin Beauvericin, then the remaining body tissues. Then, the fungus forms the conidiophores containing conidia spores, out of the dead insect body, to spread the infection to new individuals.

\section{References}

AL-Jorany, R.S., Sindab, S., Jasim Aldahwi, Hind, A., Ali. 2013. Population density and food preference of Thrips spp and Bemisia tabaci Genn. On Five cultivar of Cucumber L Cucumis sativus L. under field conditions. Third International Scientific Conference of modern technologies in agricultural production, College of Agriculture - University of Kufa in 24/4/2013.

Al-Sahaf, Fadhil, H., Mohammed, Z.K., AlMharibandFiras, M., Jawad Al-Saady. 2011. Response of Cucumber Hybrid to Chemical and Organic Fertilizers. The Iraqi J. Agri. Sci., 42(4): 52-62.

Azab, A.K., M.T. Kira. 1954. Dacusciliatus (Loew) an important new pest attacking Cucurbitaceous plants in Upper-Egypt. Bull. Soc. Fouad Entomol., 38 : 379-382.

Charnley, A.K., B. Cobb, J.M. Clarkson. 1997. Towards the improvement of fungal insecticides, pp 115-126. In Microbial Insecticides: Novelty or Necessity? H. F. Evans (ED.) Proc. BCPC Symposium, Coventry, UK.

Ferron, P., Vincant, J.J. 1978. Preliminary experiments on the use of Beauveria bassiana against Carpocap sapomonella In: E. Dicker (Ed).The use of integrated control; and the sterile insect technique for control of the codling moth. Mitteilungen de Biologischen Bundesanstaltfur Land- and for stwirs chaft (Berlin-Dahlem), 84-87.

Flaih, Sawsan Kareem. 2013. Economic Studies of Cucurbits Fruits Flies On (Cucumis sativus L.) and Evaluation of some Controlling Integrated Management Factors. A Thesis of Doctor, College of Agriculture University of Baghdad.

Hamodi, Awatif Abdul-Fatah, Mohammad Saleh Abdul-Rassoul. 2012. New record for insect TRIPs watermelon (Thysanoptera: Thripidae) Thrips palmi Karny 1925 in Iraq. Arab J. plant Protection, V.30, No.1: 142-144.

Heinz, K.M., Van Driesche, R.G., Parrella M.P. 2004. Lecani cillium (Verticillium lecanii (Zimm) zare and W. G. Omai. Biocontrol in protected culture, Bull. Publishing Batavia Illinois, P. 552.

Jassim, Hana Kadhim. 2007. Studies on the Biology of Palm Dubas Bug Ommatissuslybicus (Debergevin). Asche and Wilson. (Howoptere: Tropiduchidae) and it's Biocontrol by Some Isolates ofEntopmopathogenic fungi Beauveria bassiana (Balsomo) Vuill. And Lecanicillium (Verticillium)lecanii (Zimm)zare and W.G. Omai.

Mahdi, Hassan Suleiman Ahmed. 2000. Environmental and lifestyle study Insecticides Dacusciliatus (Loew) (Diptera:Tephritidae) And some methods of control. A Thesis of Doctor, Plant Protection Department, College of Agriculture - University of Baghdad. 102 page.

Mazel, L.I., Boucias, D.G. 1996. Effect of Fungal pathogen Baeuveria bassiana on protein synthesis of infected Spodopteraexigua. J. Insect Physiol., 42: 91-99.

Sinha, P., S.K. Saxena. 1999. Effect of culture filtrates of three fungi in 
different combinations on the development of the fruit fly, Dacus cucurbitae Coq. Annals of Plant Protection Service, 7: 96-9. fungi from the soil and their pathogenicity to two fruit fly species (Diptera: Tephritidae). J. Appl. Entomol., 132(9-10): 778-788.

Sookar, P., S. Bhagwan, E. AwuorOuna. 2008. Isolation of entomopathogenic

\section{How to cite this article:}

Husam A. Ldeen, Abdaluh Mohammed, Sawsan Kareem Flaih, Nabaa Abdulridha Mikheef and Majeed Hameed Nawar. 2016. Parasitism Efficacy of Two Isolates of the Fungus Beauveria bassianato Control Larvae and Pupae of Melon fly Dacus frontalis. Int.J.Curr.Microbiol.App.Sci. 5(6): 522-526.

doi: http://dx.doi.org/10.20546/ijcmas.2016.506.058 